\section{BESZÁMOLÓ A MABISZ 2018. NOVEMBER 22-I KONFERENCIÁJÁRÓL}

Lencsés Katalin (Magyar Biztositók Szövetsége) katalin.lencses@mabisz.hu

\section{ÖSSZEFOGLALÓ}

A MABISZ2018 novemberében tartotta IX. nemzetközi konferenciáját. Az idei rendezvény középpontjában a pénzügyi tudatosság állt. Jelen cikk erről az eseményről ad összefoglalót.

\section{SUMMARY}

The Association of Hungarian Insurance Companies (MABISZ) held its 9th conference in November 2018. This year the event focused on financial awareness. This article gives the summary of the conference.

Kulcsszavak: biztosítás, konferencia Keywords: insurance, conference

JEL: G20, G22

DOI: $10.18530 /$ BK.2019.1.90

http://dx.doi.org/10.18530/BK.2019.1.90

\section{Bevezetés}

A Magyar Biztosítók Szövetsége 2018. november 22-én tartotta IX. konferenciáját a Corinthia Budapest Hotelben. A biztosítási szektor legnagyobb konferenciája ismét kiváló alkalmat jelentett a biztosítók, a velük együttműködő vállalkozások, a szabályozói és felügyeleti döntéshozók képviselői számára a magas szintű szakmai eszmecserére. A rendezvény középpontjában ezúttal a pénzügyi tudatosság állt.

A konferenciát a MABISZ fótitkára, Dr. Molnos Dániel nyitotta meg azzal a gondolattal, hogy a digitalizációnak, innovációnak és a fogyasztói ismereteknek lépést kell tartaniuk egymással. A pénzügyi szolgáltatók számára fontos, hogy ismerjék ügyfeleiket, de legalább annyira fontos az is, hogy az ügyfelek értsék a termékeket. A szakma ezért kiemelt hangsúlyt fektet a fogyasztók tájékoztatására, és arra, hogy ez a tudás valóban segítse az ügyfeleket abban, hogy helyes és felelös döntéseket hozzanak.

Az első előadó Varga Mihály, pénzügyminiszter, miniszterelnök-helyettes volt. Előadását a gazdasági helyzet rövid bemutatásával kezdte Warren Buffetet idézve, miszerint amikor a dagály visszavonul, kiderül, ki úszik fürdőruha nélkül. Magyarország tekintetében a gazdasági háttér stabil, ugyanakkor minden vonatkozásban vannak figyelemre intő körülmények. A rejtett kockázatok között említtette a pénzügyminiszter többek között az inflációs pályát, a kamatszolgálatot, a fizetési mérleg meglévő többletének a szűkülését, valamint a versenyképességi kihívásokat. Ez utóbbi vonatkozásában kiemelt szerepe van a lakosság pénzügyi tudatosságának is. Az állam látja itt a saját feladatát, az eltökéltséget mutatja az az elfogadott hétéves kormányprogram is, melynek elemei a következők:

Felelös és észszerű lakossági döntéshozatal támogatása.

A pénzügyi tájékozatlanságból adódó bizonytalanság mérséklése.

A háztartások pénzügyi stressztűrő képességének az erősítése.

A kormány a fogyasztói tudatosság ösztönzésén túl fontosnak tarja, hogy a hatékony fogyasztóvédelem is jelen legyen. Ennek kapcsán Varga Mihály kiemelte, hogy a devizahitel problémához hasonló rendszerkockázat a biztosítási szektorban nem volt, a biztosítási díjbevételek örvendetes módon egyenletesen nőnek. Ugyanakkor, ha a magyar piac lefedettségét nézzük, akkor még van tere a növekedésnek. A pénzügyminiszter hangsúlyozta, a kormány kiemelten fontosnak tartja, hogy a lakossági megtakarítások megfelelő szinten legyenek, ezért az öngondoskodás további erősítése érdekében tervezik egy új, nyugdíj-takarékossági államkötvény bevezetését, amely kiegészítője lehet a már piacon lévő nyugdíjtermékeknek.

Dr. Pandurics Anett, a MABISZ elnöke előadása elején felhívta a figyelmet arra, hogy a digitalizáció nem most kezdődött, a folyamatot a biztosítási szakmában a közvetítö, nem pedig a technológiai cégek kezdték el. 
A legtöbb insurtech megoldás a meglévő biztosítási folyamatokat, illetve a fogyasztói élményt igyekszik javítani, de léteznek teljesen új üzleti modellben gondolkodó cégek is. A kárbejelentési és kárrendezési folyamatokra fókuszáló insurtech megoldások gyakorolják a legnagyobb hatást a fogyasztói élményre, hiszen egy olyan ponton igyekeznek a szolgáltatásminőségen javítani, ahol az ügyfelek azt leginkább igénylik.

A MABISZ-nak kiemelkedő szerepe van a pénzügyi tudatosság előmozdításában. A TKM, a Díjnavigátor, valamint a Szövetség megújult honlapja is azt mutatják, hogy a digitalizáció évtizedek óta jelen van a szektorban, csak korábban az online összehasonlítást nem hívtuk insurtech-megoldásnak. A szövetség elnöke előadása végén egy új szövetségi projektről számolt be. A MABISZ tagbiztosítóival közösen hónapok óta a kék-sárga baleseti bejelentő modernizálásán dolgozik, ami összhangban áll az MNB biztositókra vonatkozó 10 éves jövőképével. Az elnök a konferencia résztvevőit arra biztatta, hogy januárig minél többen teszteljék az új alkalmazást.

A következő előadó Dr. Kandrács Csaba, az MNB ügyvezető igazgatója volt. Itt megismerhettük a legfrissebb piaci trendeket, a felügyeleti tapasztalatokat, valamint az MNB versenyt erősítő kezdeményezéseit. Az MNB 2018. februárban publikálta 10 éves jövőképét a biztosítási piacról, melyben három lehetséges szcenáriót vázolt fel a következő időszakra. Figyelemre méltó az előadó szerint, hogy a biztosítók üzleti tervei elmaradnak a felügyelet prognózisától. Az európai trendhez történő felzárkózáshoz életbiztosítási ágban háromszoros, míg nem-élet ágban kétszeres növekedésre lenne szükség. Élet ágban továbbra is problémának látja az előadó, hogy még mindig nem elég átláthatóak és egyszerűek ezek a termékek, ugyanakkor közép- és hosszú távon van bennük potenciál. A nem-életbiztosítók piaci koncentrációjának eddig csökkenő trendje most megtorpanni látszik, ami nem jó hír az ügyfeleknek, hiszen elsősorban az ő érdekük az élénk piaci verseny. Különösen igaznak tekinthető ez a kijelentés a lakásbiztosítási piacon. A felügyelet a piaci szereplők vizsgálatát egyre szélesebb körben folytatja, és kiemelten koncentrál a fogyasztóvédelmi problémákra.

\section{Az MNB élen jár a digitális megoldások támogatásában.}

Rátérve a konferencia témájához szorosan kapcsolódó területre, Kandrács Csaba elmondta hogy a biztató innovatív megoldásokkal párhuzamosan van tér az IT fejlesztésekre, az MNB pedig élen jár a digitális megoldások támogatásában. Hosszabb távon a szabályozói támogatás több szinten is megvalósulhat, bár az EU jogszabályi kereteket figyelembe kell vennie a hazai szabályozónak. Három konkrét projekt került megemlítésre: a központi kgfb tételes adatbázis, a biztosítási és pénztári portfóliók befektetéseinek monitorozása, valamint a hitelhez kötődő biztosítások nyilvántartása. Kandrács Csaba előadását azzal zárta, hogy a biztosítási szektorban is szükség van az OBA-hoz és a BEVA-hoz hasonló garanciaalapra.

Martinovic Boris, a Mastercard igazgatója prezentációjában azt világította meg, hogy fizetési innovációknak milyen szerepük lehet a biztosításban. A card on file megoldás rögzíti a fizetési adatokat, így azokat rendszeres fizetés esetén nem kell újra és újra bevinnie az ügyfélnek. Az ismétlődő kártyás fizetési tranzakciót pedig a szolgáltató kezdeményezheti. Az előadó kiemelte, hogy a Mastercard e-commerce fizetési megoldásai támogatják a fogyasztók pénzügyi tudatosságát azáltal, hogy ellenőrzést biztosítanak a költések felett, lehetővé teszik a rendszeres, ütemezett fizetést, miközben a tranzakciók költségmentesek és követhetőek.

A kávészünet utáni első előadó Arthur Hilliard, az Insurance Europe munkatársa az európai biztosítási piacok tapasztalatait, illetve legjobb gyakorlatát osztotta meg a konferencia közönségével. Elmondta, hogy mit tesznek, mit tehetnek a piacok azért, hogy javuljon a fogyasztók pénzügyi tudatossága.

Biztosítási szempontból két kulcsfontosságú kérdés van. Az egyik a kockázattudatosság, nevezetesen, hogy a fogyasztó a számára megfelelő biztosítási fedezettel rendelkezzen. A másik pedig az, hogy az embereknek elégséges megtakarításuk legyen nyugdíjaskorukra. Az előadó részletesen ismertette, hogy milyen megoldásokkal dolgozik az európai szövetség az „Insure Wisely” kampány keretében, ahol különösen fontos szerepet szánnak az interaktív és infografikai megoldásoknak. Az Insurance Europe-hoz beérkezett eddigi visszajelzések rendkívül pozitívak, és az is kiderült, hogy a piaci szereplők eltanulják egymástól a hatékonynak bizonyuló módszereket.

Az európai szövetség összegyüitötte egy publikációban, hogy az európai biztositási szövetségeknek milyen kezdeményezései vannak a pénzügyi tudatosság erősítésére. Az anyag ösztönzi a digitális eszközök kiterjedt alkalmazását, melyek egyre szélesebb kör elérését teszik lehetővé.

Hídvégi Áron, a Századvég igazgatója egy telefonos módszerrel lebonyolított kutatás eredményét ismertette. Ebből az derült ki, hogy a magyar lakosságnak még mindig meghatározóan nagy része az államtól reméli a megfelelő ellátást nyugdíjas éveiben. Nem jellemző az aktivitás az olyan napi pénzügyi döntésekben sem, mint amilyen a szolgáltatóváltás, legyen szó bankról vagy biztositóról. Az is kiolvasható a felmérésből, hogy a fogyasztóknak sokszor pozitívabb képük van magukról és saját pénzügyi ismereteikről, mint amit a statisztikák ténylegesen mutatnak.

Ezt követően Mérö László, az ELTE egyetemi tanára az alfa generáció pénzhez való viszonyáról beszélt újszerű megközelítésben. Gyakori félelem, hogy az internet tönkreteszi a kapcsolatokat, ugyanakkor hajlamosak vagyunk átmeneti jelenségekből történelmi léptékű következtetéseket levonni. Az előadó álláspontja szerint a homo sapiens evolúciója még nem fejeződött be. Ennek kapcsán megismerhettük a két versengő darwini elméletet napjaink pszichológiájában. A biológiai darwinizmus logikája azt mondja, hogy az algoritmusok (a mesterséges intelligencia) uralma következik, átveszik a gazda szerepét. $\mathrm{Az}$ egyetemes darwinizmus logikája ezzel szemben azt állítja, hogy továbbra is mi (a génjeink, a mémjeink, a mónjaink) leszünk az urai az algoritmusainknak, gazda pedig nincs. Az eredményhirdetésre egyelőre még várni kell. 
Megtudtuk az előadásból, hogy azX, Y, Zés alfa generáció nem lázadó generáció, ugyanakkor számukra már egy szám a telefon képernyőjén ugyanolyan pénzt (vagy például megtakarítást) jelent, mint egy papír, amelyre egy számot nyomtattak.

A konferencia első felét a vezérigazgatói kerekasztal zárta, melynek részvevői voltak Erdős Mihály elnök-vezérigazgató (Generali), Kisbenedek Péter elnök-vezérigazgató (Allianz), Sztanó Imre elnök-vezérigazgató (NN), Zolnay Judit elnök-vezérigazgató (Metlife). A moderátor Lambert Gábor, a MABISZ kommunikációs vezetője volt. A kerekasztal azt a kérdést járta körül, hogy mit tesznek a biztosítók a pénzügyi tudatosságért. Megállapították, hogy 2008-hoz képest javult a pénzügyi tudatosság, a jogalkotó és a piac egyaránt sokat tanult. Abban is egyetértés volt, hogy a szolgáltatók az átláthatóság és az elérhetőség növelésével sokat tudnak tenni, és ebben sokat segít a technológia. Ugyanakkor az alkalmazások még sokáig nem fogják kiváltani a személyes értékesítést, különösen az életbiztosítások területén.

\section{A szolgáltatók az átláthatóság és az elérhetőség növelésével} sokat tudnak tenni, és ebben sokat segít a technológia.

Fontos része a munkának az értékesítők felkészítése, ők egyfajta misszionáriusként müködnek, segíthetik a pénzhez való viszonyunk tudatosabbá tételét. Az értékesítés bizalmi viszony, melynek része az edukáció, és a technológia ebben a vonatkozásban is tud segíteni a közvetítöknek.

Az iparágnak azzal is szembe kell néznie, hogy az államnak van kiszorító hatása, ha nyugdíj-megtakarításokról beszélünk, a felmérések szerint az emberek többsége még mindig az államtól várja a segítséget. Ebben a vonatkozásban a politikának is ellentétesek lehetnek a rövid és hosszú távú érdekei. Ezért is fontos, hogy a rendszerek mennyire kiszámíthatóak, illetve mennyire épülnek egymásra.

Az értékesítés kapcsán még elhangzott, hogy az információkat az ügyfeleknek emészthető formában kell megkapniuk, ami egyre bonyolultabb feladat a mostani szabályozási környezetben. Ennek kapcsán kiemelendő az a munka, amely a MABISZ Életbiztosítási tagozatán belül zajlik, és amely az életbiztosítások ügyfél-tájékoztatásának az egyszerűsítésére irányul. Végül a digitalizáció vonatkozásában megemlítésre került, hogy ez tanulási folyamatot jelent minden szektor számára, hiszen „több gól több kapura rúgásból lesz”. Célszerű ugyanakkor inkább élethelyzetekre szabott ajánlatokról beszélni, miközben az emberi attitűd lassabban fejlődik, mint a technológia. A biztosítási szakmának tehát azt az üzenetet kell közvetítenie, hogy segítünk.

A délutáni program két szekcióra vált szét, az egyik az életbiztosítások, a másik pedig a nem-életbiztosítások iránt érdeklődők számára kínált érdekességeket.

\section{Nem-élet szekció}

A szekció első előadója Kórász Tamás, a KPMG vezető informatikai tanácsadója volt, aki az azonnali fizetések bevezetésének biztosítói lehetőségeiről beszélt. Ez a megoldás a kártyaszolgáltatásokhoz hasonló fizetési sebességet és rugalmasságot biztosít, az esetleges díjak ugyanakkor a küldő felet terhelik. Újdonsága, hogy nem szükséges a használatához külön eszköz (pl. kártyaterminál). A másodlagos azonosítók használata lehetővé teszi az eddigi komplex számlaszámok használatának az elkerülését. A fizetési kérelem alkalmazható előre kitöltött díjbekérőnek és egyben fizetési emlékeztetőként, továbbá fizetési kérelemnél a díjbekérés és az átutalás jól párosítható.

Biztosítások esetében ez a fizetési mód egyszerübb dífizetést tehet lehetővé (akár az első díjnál, akár a rendszeres dífizetésnél), a kárkifizetés tényleg azonnal megtörténhet, és az intervenció is gyorsabban, illetve olcsóbban intézhető, mivel a dífizetési csúszások jelentős része csak figyelmetlenség következménye.

Krizsán Erika, az Insurance Factory ügyvezetö igazgatója azt mutatta be, hogy milyen hatásuk van az új technológiáknak a gépjárművek és a vagyonbiztosítások piacán. Az előadás végigvezetett a biztosítói értékesítési modellek négy típusán: a termékcentrikus, ügynökközpontú, ügyfélcentrikusés adatcentrikus modellen. Az onlineóriások és a startupok egyaránt arra ösztönzik a biztositókat, hogy új utakban gondolkodjanak, erre pedig a digitalizáció jó lehetőséget kínál. A bemutatott gyakorlati megoldások több előnnyel is rendelkeznek, mint a bevétel növekedése, költség csökkentése, ügyfél-elégedettség növelése, kockázat csökkentése, az árazás precizitásának finomítása, valamint a károk csökkentése.

A nem-élet szekciót egy kerekasztal beszélgetés zárta, melynek részvevői voltak Gordos József, a Pénzügyminisztérium föosztályvezetö-helyettese, Nagy Koppány, az MNB felügyeleti igazgatója, Kaszab Attila, a K\&H Biztosító vezérigazgató-helyettese és Máhig Attila, a Groupama szolgáltatási ügyvezető igazgatója. A moderátor Kerékgyártó Csaba, a MABISZ főtitkárság vezetője volt.

\section{Az ügyfeleknek nem könnyü a sok tájékoztató dokumentum kö-} zött eligazodni, miközben mindezek az ő érdekükben születnek.

A beszélgetés a nem-életbiztosítás aktuális kérdéseit, különösen a lakásbiztosítás és a gépjármű-biztosítás területét járta körbe. Arra keresték a választ a résztvevők, hogy melyek voltak a szabályozási változások főbb kihívásai szabályozói, felügyeleti oldalon, valamint a lakossági termékek értékesítésében és a szolgáltatásban. Nagy szabályozási változások nem várhatók a következö években, hiszen a Szolvencia II, az IDD, IFRS, GDPR, PRIPS szabályainak beépitése a hazai jogszabályi környezetbe megtörtént. A Felügyelet is szabályoz, de inkább a jogalkotást támogatják. Az ügyfeleknek nem könnyű a sok tájékoztató dokumentum között eligazodni, miközben mindezek az ő érdekükben születnek. A biztosítók szerint az IPID az ügyfelek tájékozottságát növeli, segíti a megfelelő termék kiválasztását, de ezzel tovább nőtt a szerződéskötés 
elött áttekintendő dokumentumok száma. Az európai jogszabályok implementálása sokba kerül a biztosítóknak, szakmailag a GDPR bizonyult a legnehezebb feladatnak.

Kérdés, hogy a digitalizáció rohamos terjedése miatt milyen főbb kihívások jelentkeznek. A szabályozás ezen a területen már rendelkezésre áll, a műszaki megoldások a szakemberekre várnak. AzMNB támogatja az innovációt minden területen. A MABISZ legyen proaktív, például indítson olyan munkacsoportot, amely a biztosítói adminisztráció csökkentésével foglalkozik, áttekinti a jogszabályokat, hogy például csak a minimálisan szükséges dokumentumok kerüljenek az ügyfélhez. A munka már elkészült a MABISZ-ban, az utolsó egyeztetések zajlanak, és hamarosan megküldik az MNB-nek is. A jogalkotó szívesen fogadja az egyszerüsítést, digitalizációt lehetővé tevő jogszabály-módosítási javaslatokat. A biztosítók szerint a fiatal generáció digitális megoldást vár ügyfélként, de biztosításközvetítőként is. A biztositásközvetítést vonzó pályává kell tenni, mert egyre csökken - különösen a fiatalok körében - az utánpótlás.

A konferencián több előadás foglalkozott a lakásbiztosítással. Ezen a területen magas a penetráció, fedezetet nyújtanak a biztosítások a katasztrófakockázatokra, európai szinten is megállják a helyüket a magyar lakásbiztosítási termékek. Kérdés, hogy milyen jövője van a lakásbiztosítások piacának? Kötelező lakásbiztosítás bevezetése nincs napirenden szabályozási oldalról, amit a 72-73 százalék körüli penetráció is alátámaszt. Arra kell törekedni, hogy fogyasztói oldalról könnyebb legyen összehasonlítani a termékeket. Az MNB szerint a magyar lakásbiztosítási piacon nem megfelelő a verseny intenzitása, magas a piaci koncentráció, nincs igazi díjverseny, túl alacsonyak a kárhányadok. Közös gondolkodás kell a piaccal, hogy a lakásbiztosítás jobban szolgálja az ügyféligényeket. Ennek megfelelően különösen a szolgáltatások színvonalára kell helyezni a hangsúlyt. Csökkenteni kell a koncentrációt, növelni a versenyt, hogy ne négy szereplő uralja a piacot. A biztosítók szerint 2018 jó év volt a lakásbiztosításban, de nagyon elszabadultak az anyagárak, nőtt a szakemberek munkadíja, aminek van hatása az eredményre. Az ügyfelek főként csomagbiztosítást vásárolnak, de egyre többen választanak kiegészítő biztosításokat is, melyekből bőséges a kínálat a piaci szereplőknél. A lakásbiztosítás ügyfeleire nem jellemző a biztosítóváltás. A biztosítók szerint jó minőségű a kárrendezés. A tapasztalatok azt mutatják, hogy a fö biztosítás a lakosságnál a lakásbiztosítás, ezért erre nagyon odafigyelnek. Európai szinten is nagyon jó kondíciókkal köthetők a hazai lakásbiztosítások, különösen az elemi károkra. Az értékesítési csatornáknak, biztosításközvetítőknek, bankban történő biztosításkötésnek is jelentős költségük van. Vannak olyan évek, amikor árvíz, viharok stb. miatt már nem lesz olyan jó az eredmény. Ezekre az évekre is tartalékolni kell. Az ügyfél-elégedettség növelése kiemelt célkitűzés, az ennek eléréséhez szükséges megoldásokra törekszik az MNB.

A kerekasztal befejező témaköre a gépjármü-biztosítások (kgfb, casco) területén jelentkező kihívásokkal foglalkozott. A szabályozás oldaláról van mozgás az Unióban is. Változhat a járműhasználat fogalma, új kártalanítási szervezet is beléphet, bár ezt nem támogatják.

Az MNB nem lát különösebb anomáliát a kgf-piacon, a versenyt is megfelelőnek ítélik. Inkább a lakásbiztosításnál vannak teendők a verseny növelése érdekében. A biztositók részéről felvetődött, hogy miért 15 százalék a biztositási adó? Miért nem 10 százalék, mint más vagyon- biztosításoknál? A magas szervizdíjakat a munkaerőhiány is okozza. Nőtt a jármüpark, több a baleset. Mindezek éreztetik hatásukat a biztosítók eredményeiben is. A flották és a buszok eddig alul voltak árazva. Nagyon sokba kerül a biztosítóknak a személyi sérülés, különösen a külföldi baleseteknél. A kárgyakoriság várhatóan nem nő tovább, az átlagkárok viszont igen (a munkadíjak, alkatrészárak miatt). Az autóipari technológia egyre fejlődik, amihez a biztosításoknak is igazodniuk kell.

\section{Élet szekció}

Az élet szekció Molnár István előadásával nyitott, aki az Asseco Central Europe Magyarország Zrt. vezető üzleti tanácsadója. Az előadó személyes tapasztalatait osztotta meg a közönséggel rendkívül élvezetes módon, a biztosítói rendszerek bevezetéséről Nigériában és Ghánában. A projekt tárgya a meglévő rendszerek helyettesítése és a technológiai innováció a WAPIC biztosítási csoporton belül. A rendszerbevezetéssel kapcsolatos legnagyobb kihívás az „egzotikus piac” sajátosságainak elsajátítása, a területi és kulturális különbségek áthidalása volt. Ilyen helyi sajátosságnak tekinthető az egyszerü termékszerkezet, hogy nincsen díjábla, vagy az, hogy a kockázatelbírálás a szerződéskötés után is megtörténhet. További nehézség, hogy sem egyedi személyazonosító, sem pedig fizetésazonosító nem létezik ezeken a piacokon. A biztosítók ezért nem építhetnek a tradicionális csatornákra díjbeszedésnél és kárkifizetésnél, ezért is van itt terepe a pénzügyi innovációnak és a fintech megoldásoknak.

Dr. Tóth László, a Budapesti Corvinus Egyetem docense egy egyre népszerủbb tudományágat képviselt, a viselkedés közgazdaságtant. Az előadás a tudatos megtakarítás korlátait járta körbe. Megtudhattuk, hogy az emberek ún. mentális könyvelést folytatnak, a pénzeszközöket három számlán „kezelik”: ezek a jelenlegi jövedelem, forgótőke és jövőbeli jövedelem számlák. A megszerzett jövedelmet könnyebben vagy kevésbé vonakodva fordítják vásárlásra a kategorizálás vagy címkézés függvényében. A nagy összegeket a forgótőkeszámlához tartozónak könyveljük el, és általában megtakarításra kerülnek, míg a kisebb összegek jelenlegi jövedelemnek minősülnek, és könnyebben elköltjük. A fogyasztási határhajlandóság úgy nő, ahogy a váratlan bevétel mérete csökken. Ha az embereknek a vásárlásra kell fordítaniuk a forgótőkeszámlán található pénzüket, kevésbé hajlandóak erre, mint ha elegendö jövedelmet kapnak.

Ahogy a jövedelmeket különböző kiadási kategóriákba soroljuk, ugyanúgy az emberek a pénzt különböző megtakarítási kategóriákba sorolják. A mentális könyvelés további példája az egyidejü kölcsönfelvétel és megtakarítás, amit gyakran alkalmaznak az emberek annak biztosítására, hogy megtakarításaikat bizonyos célok eléréséhez használhassák fel. Mivel a hitelfelvétel és a megtakarítás általában különböző kamatlábakon történik, ez a viselkedés irracionális, és adósságrejtélynek nevezzük

A viselkedés közgazdaságtan ezekre a viselkedésmintákra alapoz a bemutatott „SMarT Program” (Save More Tomorrow) esetében, amikor a programba bevontak azt vállalták, 
hogy a megtakarításaikat a következő fizetésemelésekből növelik. Ennek hatására az alanyok már nem a jelenlegi fogyasztásuk és a jövőbeli fogyasztásuk között döntenek, hanem két jövőbeli fogyasztás között, így a megtakarítást nem élik meg veszteségnek. A program eredménye három fizetésemelés után az volt, hogy azok, akik csatlakoztak a SMarT programhoz, megnövelték megtakarítási arányukat 3,5-ről 11,6 százalékra. Azoknál, akik nem csatlakoztak a SMarT tervhez, a megtakarítási ráta 5,3 százalékról csak 7,5 százalékra nőtt.

Az élet szekciót is egy kerekasztal beszélgetés zárta, melynek részvevői voltak Juhos András, az UNIQA elnöki tanácsadója, Kuruc Péter, a K\&H Bank ügyvezető igazgatója, Schaub Erika, a Generali igazgatósági tagja és Erdei László, az UFS Group Pénzügyi Tervezö Kft. ügyvezető igazgatója. A moderátor Lencsés Katalin, a MABISZÉletbiztosítási tagozatának vezetője volt. A beszélgetés felvette az előző előadás fonalát, és a résztvevők azt próbálták körbejárni, hogy van-e nemzeti karaktere a magyar befektetőnek, valóban igaz-e az, amit egy friss nemzetközi kutatás kihozott, miszerint a magyar emberek más országokhoz képest lényegesen türelmetlenebbek és kockázatkerülőbbek, ami nem kifejezetten jó kombináció, ha megtakarításokról van szó. A kihívásokat mindenki érzékeli, ugyanakkor láthatóak pozitív jelek az életbiztosítási piacon, különösen, ha a nyugdíjbiztosítási termékek értékesítési számait nézzük. Árnyaltabbá válik ugyanakkor a kép, ha a teljes megtakarítási piacot nézzük. Az életbiztosítások növekedésének dinamikája, illetve részesedése a lakossági megtakarításokon belül (kevesebb, mint 5\%) tendenciaszerüen elmarad az egyéb megtakarítási termékektől. Az összehasonlító európai adatok is azt mutatják, hogy a magyar életbiztosítási piacnak még lenne hová fejlődnie.

\section{A gyerekbetegségeket a KID esetében már maga a jogalkotó is felismerte, és törekszik azok korrekciójára.}

Kérdés, hogy a fejlődést elősegíti-e a közelmúlt európai szabályozása, ami kiemelten a befektetési termékek transzparenciájának növelésére, az összehasonlíthatóságra és az érdekkonfliktusok kezelésére irányul (PRIIPs rendelet, IDD irányelv), másfelől ugyanakkor szignifikáns módon megnövekedő tájékoztatási kötelezettséggel, illetve adminisztrációval jár. A szabályozás piaci fogadtatása egyelöre vegyes, bár a transzparenciára és összehasonlíthatóságra vonatkozó jogalkotói szándékot mindenki támogatja. A gyerekbetegségeket, különösen a KID esetében már maga a jogalkotó is felismerte, és törekszik azok korrekciójára. Abban ugyanakkor egyetértés van, hogy a megtakarítás, illetve a nyugdijtermékek jövője a kiszámítható és stabil adópolitikában és az egyszerűen igénybe vehető termékinnovációban van.

Az eseményt a szokásos búcsúkoccintás zárta, ahol a konferencia vendégei még tovább folytathatták a gazdag program megvitatását. Az érdeklődők az előadások anyagait a MABISZ konferencia honlapján megtalálják: http://mabiszkonferencia.hu/ 